\title{
Association Between Serious Psychological Distress and Loneliness During the COVID-19 Pandemic: A Cross-Sectional Study with Pregnant Japanese Women [Corrigendum]
}

\author{
Takeda $\mathrm{T}$, Yoshimi $\mathrm{K}$, Kai $\mathrm{S}$, Inoue $\mathrm{F}$. Int $J$ Womens \\ Health. 2021;13:1087-1093.
}

The authors have advised that they mistakenly compared the data with that of postpartum mothers instead of pregnant women in the Discussion section on page 1091.

Second paragraph, second sentence, the text "The proportion of women with a K6 score $\geq 10$ in our survey was $37.7 \%$, which is significantly higher than that in the large- scale 2020 survey $(13.9 \%, \mathrm{n}=2977 ; p<0.0001$, Pearson's chi-square test, Cramer's V $=0.26$ );" should read "The proportion of women with a K6 score $\geq 10$ in our survey was $37.7 \%$, which is significantly higher than that in the large-scale 2020 survey $(13.2 \%, \mathrm{n}=4798 ; \mathrm{p}<0.0001$, Pearson's chi-square test, Cramer's V $=0.25)$;".

The authors apologize for this error and advise it does not affect the results of the paper.

\section{Publish your work in this journal}

The International Journal of Women's Health is an international, peerreviewed open-access journal publishing original research, reports, editorials, reviews and commentaries on all aspects of women's healthcare including gynecology, obstetrics, and breast cancer. The manuscript management system is completely online and includes a very quick and fair peer-review system, which is all easy to use. Visit http://www.dovepress.com/testimonials.php to read real quotes from published authors. 